\title{
Metallurgy and materials Economic and environmental analyses of biomass torrefaction for injection as pulverized material in blast furnaces \\ http://dx.doi.org/10.1590/0370-44672020740101
}

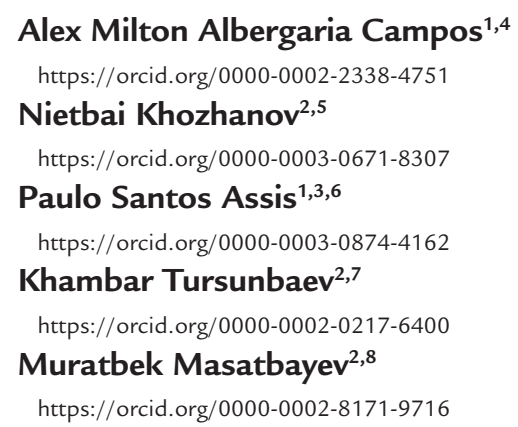

${ }^{1}$ Universidade Federal de Ouro Preto - UFOP, Universidade do Estado de Minas Gerais - UEMG, Rede Temática em Engenharia de Materiais - REDEMAT, Ouro Preto - Minas Gerais - Brasil.

${ }^{2}$ Taraz State University named after M Kh Dulaty, Department of Land Reclamation and Agronomy, Taraz - Jambyl Region - Kazakhstan.

${ }^{3}$ Universidade Federal de Ouro Preto - UFOP, Escola de Minas, Departamento de Engenharia Metalúrgica e de Materiais,

Ouro Preto - Minas Gerais - Brasil.

E-mails: ${ }^{4}$ alexcampos88@yahoo.com.br, ${ }^{5}$ khozhanov55@mail.ru, ${ }^{6}$ assis.ufop@gmail.com, ${ }^{7}$ khambar2016@yandex.ru, ${ }^{8}$ m-muratbek@list.ru

\begin{abstract}
Biomass was the first material used as a fuel by humanity, being replaced by fossil fuels after the industrial revolution. With the growing of environment discursions and the effects of $\mathrm{CO}_{2}$ emissions, biomass has been gaining strength as a potential alternative to fossil fuels, especially for steelmaking, which is responsible for about 5 to $10 \%$ of all $\mathrm{CO}_{2}$ emitted. It is known that biomass, compared to fossil fossils, has a higher volatile content, high moisture and lower calorific value. On the other hand, it has a higher hydrogen content and lower sulfur content (important for the steel industry), in addition it is considered neutral in $\mathrm{CO}_{2}$ emissions. Torrefaction, heating biomass at a temperature between $200-280^{\circ} \mathrm{C}$ in an oxygen free atmosphere, is an interesting treatment to adapt biomasses for use in the steelmaking processes, mainly in the pulverized material injection into the blast furnace. $\mathrm{PCI}$ is an extremely important process for the production of iron in the blast furnace, due to its ability to reduce coke consumption and optimize the operation of the reactor. This article comes with the purpose of presenting a bibliographic review about PCI technique, torrefaction process, biomasses and its applicability in the steel industry. In addition, an economic and environmental analysis of the possible use of biomass in steelmaking processes will be presented. Results shows that the use of torrefied biomass in the injection process is interesting, generating savings of 10 dollars and reduction of $264 \mathrm{~kg}$ in $\mathrm{CO}_{2}$ emissions per ton of hot metal, with a replacement of $50 \%$ of the coal used by biomass.
\end{abstract}

Keywords: biomass, iron production, steelmaking, torrefaction, blast furnace.

\section{Introduction}

Steelmaking processes have a high energy consumption from fossil fuels, being responsible for $7-9 \%$ of world $\mathrm{CO}_{2}$ emissions. To produce 1.85 billion tons of steel in 2019, it was estimated that $3.3 \mathrm{Gt}$ of $\mathrm{CO}_{2}$ was emitted, putting steel processes at the forefront of the emission reduction program (Holappa, 2020).

The blast furnace process is the greatest $\mathrm{CO}_{2}$ emitter (about 70\%) in steelmaking, due to the high consumption of fossil fuels (Orth, 2007). A widely used technique, which aims to reduce coke consumption, is pulverized material injection known as PCI (Pulverized Coal Injection). This technique has a strategic function for steelmakers because in addition to reducing the consumption of coke, it is important for the reactor operation due to the short response time. An important in- dicator of the process quality selecting materials to inject and for analyzing its performance is the replacement rate, which is the amount of coke or charcoal that is saved when you inject materials through the tuyers. The material commonly used today is coal, however there are several researches showing alternative materials replacing coal, mainly waste from other processes.

One of the alternatives, mainly 
for mitigating environmental impacts, is the injection of biomass in the blast furnaces. Biomasses usage would reduce $\mathrm{CO}_{2}$ emissions and also decrease the cost of production, since biomass is usually cheaper than coal. In comparative terms, it will be possible to see that the coal cost is around US\$ 180,00 and biomass ranging from US\$ 80 to 120 .

In general, biomass has a high content of volatile materials, a high moisture content and a low fixed carbon content. These properties greatly influence the process of pulverized materials injection, which suggests a pretreatment

\section{Methodology}

First, a literature review was made to contextualize, showing particularities of PCI technique and the possible use of biomass, as well as torrefaction treatment and the advantages it brings to before use. In literature, it is possible to find several heat treatments for biomass. These include gasification, pyrolysis, torrefaction and carbonization. These treatments heat the biomass at determined temperatures, often without oxygen, increasing the fixed carbon by the elimination of volatile materials.

For PCI, the most interesting process is the torrefaction, which heats the material in temperatures between $220{ }^{\circ} \mathrm{C}$ and $280{ }^{\circ} \mathrm{C}$ without oxygen, increasing the properties of materials. This treatment can enable the use of biomass in pulverized material injec- tion into blast furnace, since it changes some properties of biomasses like fixed carbon, volatiles and calorific value.

The aim of this article is to present a review of pulverized material injection and biomass torrefaction, showing possibilities for using biomass, replacing part of the coal in the PCI process. Finally, an economic and environmental analysis of the gains that biomass usage can generate for the steel industry will be identified. It will be possible to note that torrefied biomass proves to be a good alternative for the PCI processes, reducing cost and greenhouse gas emissions.

\section{Discussion}

\subsection{Pulverized coal injection}

This technique had its origin documented in the nineteenth century in France and later was patented in Germany. PCI has been an evolution over the years, driven mainly by the economic aspect, since it is possible to reduce the amount of material carried by the top of blast furnace. Over the years, the PCI became a consolidated technique and the increase in productivity in the blast furnaces was undeniable (Assis, 2003).

Auxiliary fuel injection is one of the main thermal variables control on blast furnace and is used due to the short response time. Its availability is limited in the lower range by the minimum injection rate and the upper range by the minimum acceptable flame temperature, there is a minimum and a maximum amount to be injected without changing the operational conditions of the blast furnace (Mourão, 2011).

The raw material must pass through a process that will suit it for injection in the combustion zone of the blast furnace. Grinding is first done to achieve optimum grain size and drying to eliminate moisture. Then the material must be fluidized by mixing it with a gas, air or nitrogen, and pneumatically transported and distributed by the tuyeres (Assis, 2014).

The material is injected into the blast furnace inside the raceway where it passes through devolatization and burning, adapt biomass for the process. Second, a critical analysis of some data from literature was carried out and some points discussed in a technical way to verify the viability of the treatment and biomass uses. Finally, an environmental and economic analysis was done to measure, in an empirical way, the gains that steel companies can achieve with replacing a fossil fuel with a biomass. generating energy and gases necessary for the process. Firstly, the particle is heated causing the degassing and ignition of the volatiles, which happens by convective heat exchange with the blown air and radiant with the combustion zone. Second, there is the burning of volatiles, that is, pyrolysis that releases the high hydrogen content in volatile material. Finally, the residue on the particle that is practically carbon, is burned. These steps may occur sequentially or simultaneously depending on factors, such as particle size, composition, heating and the amount of oxygen available (Assis, 2008).

Aspects related to the quality of the injected material also influence blast furnace operating parameters, not only in the thermal control, but in other conditions such as permeability, burden distribution and others. Ash content, for example, can influence phenomena within the reactor such as "Bird nest", which is the accumulation of unburned material in the combustion zone. This feature is closely linked to the quality of the injected material.

One important parameter to select materials for injection is the replacement rate. The replacement rate is the amount of coke replaced by the amount of material injected. In other words, the replacement rate measures the efficiency of the injection process. In the early 1990s, Hunty et al. (1990) proved in his studies that the replacement rate varies with the rank of coal. Brouwer et al. (1992) and Brouwer and Troxopeus (1991) proposed the calculation of the corrected replacement rate for the KNHS blast furnace in Hoogovens and Ijmuiden, which was based on the chemical properties of materials. These formulas are easily found in literature and can be used for biomasses, for example, in order to have an idea of the behavior of these materials in the injection process.

A variety of research has been published evaluating the impact of using biomass on blast furnace injection using approximation models. These models range from blast furnace combustion zone-simulation models, one-dimensional static models, three-dimensional models, and numerical models. Laboratory results suggest that the use of biomass in blast furnace injection may increase the degree of iron ore reduction compared with coal (Suopajärvi, 2017).

There are several biomasses that can be used for blast furnace injection, and many have been studied, such as sawdust, sawmill waste, agribusiness waste, wood, charcoal, roots and others. The carbon content of the biomass is lower compared to that of solid fuels. Oxygen content is around 40\% which decreases the energy contained in these materials. Fixed carbon is low while volatile material 
content is high. The amount of sulfur is also low, which is an advantage for blast furnace production. The moisture content of biomass is considered high and can be a problem, but treatments like torrefaction and carbonization, can solve this problem (Suopajärvi, 2013).

For Babich (2019), biomass can be used in steel plants in three different ways:

- injection into shaft furnaces or electric arc furnaces.

- incorporation into the burden materials or into the coal blend for cokemaking;

- generation of a reducing gas.

According to Wei (2017), biomass can be injected into blast furnaces in three ways: pulverized solid, bio-oil or biogas. The most common studies use pulverized solids, mainly fine charcoal, where the

\subsection{Biomasses}

The use of biomass is the oldest method for supplying energy to humanity. However, the use of biomass as a renewable and universal source of energy must undergo a development of technology and reputation. In addition to the positive environmental effects of using biomass as a fuel source, there are several economic and social aspects to consider.

Biomass can be defined as the total mass of organic substances that occur in a habitat. The forms of biomass on planet are many and varied. According to their origin, biomasses are divided into four categories: crops for energy production, post-harvest waste, organic by-products and organic waste. For use biomass in steelmaking processes, the most interesting categories are energy harvests and post-harvest residues, which are the types of biomass considered in this study injection of $200-225 \mathrm{~kg} /$ ton of hot metal, in large blast furnaces may be feasible.

Assis (2014) performed several combustion tests using pulverized biomasses mixed with coal. The results showed that many biomasses have a higher combustion rate than coal. This fact was related to the high reactivity of biomass, as well as the larger specific surface compared to coal, which influences the combustion process.

The main point is that pulverized material injection is important for costs reduction, since it is possible to inject materials of lower cost than coke and charcoal. There is a real possibility of using biomass, which can be considered neutral in $\mathrm{CO}_{2}$ emissions. This material can be an interesting alternative since it is available at a low cost. Furthermore, with the increasing pressures on environmental

(Cortez, 2008).

Moreover, during biomasses growth, carbon dioxide is consumed during photosynthesis and oxygen is produced, which can generate a positive for GHG emissions. Another advantage is that its costs are practically associated with transportation and processing, since they are often agribusiness waste. In addition, it generates employment and development in the areas where it is obtained, since it is located outside the major centers.

Biomasses, when compared to fossil fuels commonly used in the steel industry (coke and coal), have lower carbon, sulfur, ashes, calorific value and a higher content of volatiles, hydrogen and oxygen. Taking only these characteristics, biomass may not be viable for use in steelmaking processes, but treatments such as torrefaction can be issues, this material can be strategic for countries to replace fossil fuel.

The biomass available, such as agribusiness waste, is not ready to be used directly in steelmaking processes. These have a high moisture content, volatile materials and a coarse granulometry for injection. But these problems have some solutions, one of them is torrefaction, which can adapt it to the process by improving grindability, decreasing volatile content and increasing fixed carbon. Another important consequence is the elimination of moisture and improvement of the calorific value. Therefore, discussions and research about the use of biomass will be of main importance for the survival of the blast furnace with the new goals of reducing greenhouse gas emissions.

performed where biomass properties can be improved. In addition to chemical properties, biomasses differ in their physical properties and are characterized by lower density and higher porosity when compared to fossil fuels.

Economic constraints are analyzed at two levels. Firstly, it is necessary to know if the biomass to be exploited for energy has no other uses (industrial or food). Secondly, whether all costs of exploited biomasses are compatible with energy benefits and comparable with other fuels. Finally, technological constraints are due to the existence or otherwise of reliable processes and operations to convert biomass into fuels.

Table 1 shows some properties of biomasses, mainly waste from agribusiness, which have a great potential to be injected in the blast furnace.

Table 1 - Characterization of some materials for blast furnace injection.

\begin{tabular}{c|c|c|c|c|c|c}
\hline Biomass & \% C & \% H & \% Ash & \% Volatiles & \% Moisture & References \\
\hline Charcoal & 69.7 & 3.2 & 7.73 & 25.8 & 0.63 & Assis (2014) \\
\hline Moringa Husk & 48.84 & 6.53 & 2.36 & 76.60 & 1.47 & Campos (2018) \\
\hline Eucalyptus Husk & 50.10 & 5.42 & 2.43 & 68.73 & 5.77 & Assis (2014) \\
\hline Sugarcane bagasse & 46.40 & 4.68 & 4.33 & 75.03 & 7.03 & Du (2014) \\
\hline Elephant Grass & 40.00 & 5.36 & 13.50 & 69.95 & 0.10 & Assis (2014) \\
\hline Rice Husk & 43.4 & 4.33 & 9.55 & 73.18 & 0.10 & Du (2014) \\
\hline Corn Cob & 45.5 & 6.70 & 1,16 & 81.31 & 0.79 & Ramos e Paula (2011) \\
\hline Corn Straw & 44.80 & 6.80 & 1.58 & 81.68 & 0.31 & Ramos e Paula (2011) \\
\hline Torrefied Sugarcane Bagasse & 53.33 & 4.72 & 12.33 & 67.38 & 0.50 & Dong (2005) \\
\hline Torrefied Eucalyptus Husk ${ }^{*}$ & 55.81 & 4.87 & 0.70 & 75.20 & 0.05 & Dong (2005) \\
\hline
\end{tabular}

*Torrefied in a temperature of $273{ }^{\circ} \mathrm{C}$ for one hour. 
It is possible to note that biomasses have some important characteristics for the process that can make its use feasible. The higher hydrogen content can be interesting, since it reduces the iron ore in a more endothermic way, that is, it requires less energy for this process. Volatiles, despite being high for fresh biomass, in a certain amount, it is interesting in injection, especially when there are high injection rates. In addition, biomasses generally have

\subsection{Biomass torrefaction}

The most common pre-treatments used for biomass are torrefaction, pyrolysis, gasification and carbonization. The difference between them is temperature and treatment time. These treatments are already used to transform biomass, not for the steelmaking process but mainly in the energy sector. As torrefaction is a process with lower investment and operational costs, it becomes more interesting for steel companies to adopt it for biomass use in their processes. Therefore, this process will be emphasized here, which is the most viable for the study in question.

Biomass torrefaction is a process where biomasses are heated between $220^{\circ} \mathrm{C}$ and $300^{\circ} \mathrm{C}$, although some authors recommend not to exceed the limit of $280^{\circ} \mathrm{C}$. It is also recommended that torrefaction be carried out in a neutral lower sulfur content than coal, which is very interesting for subsequent processes.

Another important point to note is the effect of torrefaction in biomass properties. There is a significant decrease in volatile content and a consequent increase in fixed carbon. On the other hand, there is an increase in ash, but not for being unviable, since coal has values around $12 \%$ of ash.

Finally, it is important to understand

or reductive atmosphere, to inhibit material oxidation or ignition. Under these conditions, moisture is removed, and hemicellulose degrades, causing acetate release, as well as phenols and other low calorific value compounds. Lignin and cellulose also undergo a soft depolymerization. The conversion efficiency varies between $60 \%$ and $80 \%$ depending on temperature conditions under which the process is carried out. In the end, the material has intermediate characteristics between the charcoal and original biomass. Torrefaction process aims to concentrate biomass energy in a short time and obtain high yield, operating with low heating rates and moderate temperatures to allow volumes of greater calorific value retained in a solid product called torrefied biomass (Cortez, 2008). that just the evaluation of the biomass chemical properties is not enough to select materials for injection. Other factors, inherent to the process, such as availability, logistics and technologies for treatment must be evaluated. In addition, that investments will have to be made, mainly in equipment and technologies for the treatment of biomass before its use, as seen above, this treatment can greatly improve the performance of these biomasses.

The first publications on biomass torrefaction technologies date from the beginning of the $20^{\text {th }}$ century and were commonly used to remove moisture from the material (Cortez, 2008). Since then, technologies have been developed, especially in the period when there was a high price of oil. Unfortunately, there was a decrease in interest as biomass was unable to compete with fossil fuels, which became accessible again.

A technology for wood torrefaction was presented by Arcate (2000), which can be replicated for other biomasses, however it is suggested for high-scale production due to the complexity of the equipment. This equipment profile would fit in the steel industry where it would be able to supply the pulverized material injection. Figure 1 shows a scheme of this technology.



Figure 1 - Airless dryer system for biomass torrefaction (Arcate, 2000).

Torrefied biomass properties depend on processing time and temperature. For each combination of temperature, it is possible to get different properties for biomass, since fixed carbon increase and volatiles decrease with these parameters. Cortez (2008) list some common characteristics for torrefied biomass as:

- High energy density- Volatiles with high calorific value are conserved in the material;

- Hydrophobia- Due to the physicalchemical transformation, the absorption of moisture is practically zero during storage. The equilibrium humidity stabilizes at around 3\%;

- Good grindability- Torrefied biomass becomes grindable, which facilities it uses in steelmaking processes.

Untreated biomass can have some disadvantages as fuel that include relatively high moisture content, heterogeneous physical structure and properties, non-uniform particle size, low energy density and biodegradability. These cause problems during transport, handling, conversion, and storage and can also limit 
the number of applications. For example, biomass fibrous structure is less grindable than coal and this characteristic is particularly relevant when co-firing biomass in pulverized coal combustion systems as different grinding equipment may be required for the two fuels (Dong, 2015). In the other hand, if biomass previously undergoes torrefaction treatment, it can be ground without major problems.
Dong (2015) evaluated the grindability of some biomass, which passed through the torrefaction process at different temperatures. Their results are shown in Figure 2.

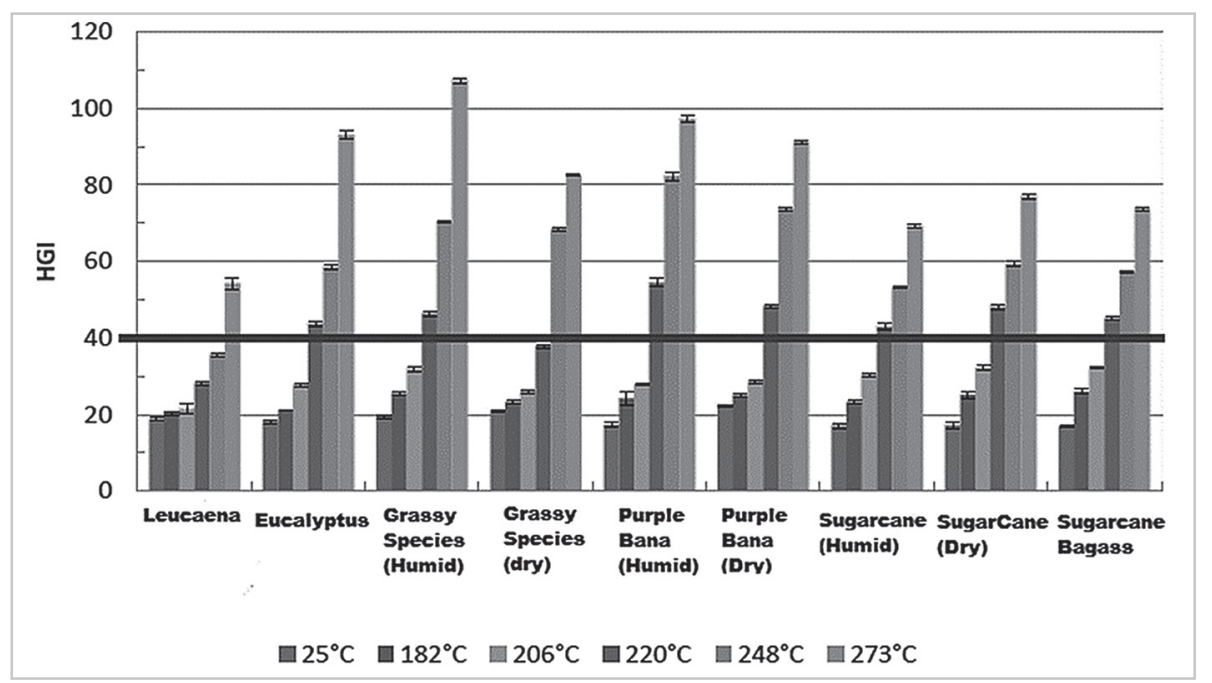

Figure 2 - Evolution of HGI when torrefaction temperature increases for some biomasses (Dong, 2015).

It is possible to see that when the torrefaction temperature increases the HGI (Hardgrove Gindability Index) increases. Some Australian coal, commonly used in the PCI process in steel mills presents a HGI value between 47 and 89 which can be compared with biomasses treated at a temperature up to $220^{\circ} \mathrm{C}$. Fresh sugarcane bagasse has a very low HGI (17) compared to coal, which means that sugarcane bagasse requires more energy for grinding. For temperatures higher than $220^{\circ} \mathrm{C}$ sugarcane bagasse HGI value grows rapidly reaching a value of 73 for the temperature of $273^{\circ} \mathrm{C}$. According to Dong (2015), the minimum effective torrefaction temperature for the sugarcane bagasse is $211^{\circ} \mathrm{C}$, which HGI has a value of 40 .

Particle size reduction is a process with high energy consumption. No studies on the influence of torrefaction energy consumption for biomasses were reported in literature. Energy-related studies using different types of grinding processes for different torrefaction conditions and material properties may help to understand the advantages and possible disadvantages of the biomass pre-treatment step.

Torrefied biomasses generates a greater amount of particles with diameters smaller than $1 \mathrm{~mm}$, allowing the particles to be heated rapidly. It is suggested to pulverize biomasses immediately after torrefaction, as the temperature at the end of the treatment (approximately $300^{\circ} \mathrm{C}$ ) may favor the pulverizing process. Studies should also be developed to evaluate the energy consumption of different types of mills during the pulverization of torrefied biomasses, evaluating the temperature and residence time parameters during torrefaction and grain size distribution. Generally in PCI, the grinding of coal is done together with drying which shows that the process can be adapted for biomass.

Another important gain with the torrefaction of biomass is the change in chemical properties, making them more suitable for use in steel industry. It is possible to see in Table 2 the effect of torrefaction in some biomasses properties. Note that there is a gain in fixed carbon, as well as a reduction of volatiles.

It is possible to see that torrefaction is viable because it improves the characteristics of biomasses. Some important points for the use in PCI is the increasing of fixed carbon, this is an important factor for the process because it increases replacement rate and calorific value. The need for oxygen enrichment to maintain the temperature in combustion zone also decreases with increasing fixed carbon. In addition, fixed carbon may be important in blast furnace permeability, because it suggests a lower content of volatiles that can evolve and degraded coke or charcoal. It can be seen in the table that as the torrefaction temperature increases, the fixed carbon increases, which is inversely proportional to the volatile content, which decrease with increasing temperature.

It is known that high amount of volatiles in the material is associated with a high combustibility. Fragoso (2018) says that this occurs because as the volatile content increases, the proportion of gases in relation to char is greater. Homogeneous combustion reactions of volatiles with oxygen are more effective compared to the heterogeneous reaction of oxygen with the solid particles of char. Despite this, volatile values above that specified by the blast furnace causes an increase in the volume of gases generated, contributing to the instability and degradation of coke or charcoal. Another point is that the replacement rate decrease when volatiles increase, but for high injection rates, the decrease in replacement rate is lower.

With these analyses, it is possible to see that the torrefied biomass is superior to fresh biomass for the PCI process. This further increases the alternatives that the steel sector has for replacing coal with clean and renewable sources, thus adapting its processes to the new environmental order of the world. It is clear that economic factors must be assessed to justify such investments. For this, greater technological development in equipment is necessary to adapt the existing ones to the reality of the steel industry. However, due to the complexity of steel equipment, this probably will not be an obstacle to torrefied biomass uses in PCI. In addition, it is possible to form agreements with biomass suppliers so that they already supply torrefied biomass, adding value and decreasing a process in steelmaking plant.

Finally, one could not fail to com- 
ment on the Torero project. Torrefying wood with ethanol as a renewable output aims to demonstrate a concept of technology of cost, resources and energy from a raw material of wood residues, integrated into a large-scale steel plant.

According to the European Commission (Torero, 2021), the stages of the Torero process are basically:

1. Wood residues are converted into biofuels by torrefaction;

2. Biocoal replaces coal in blast furnaces;

3. Carbon monoxide in exhaust gases from blast furnace is microbially fermented in bioethanol.

Torero's goal is to create a value chain for wood waste, which currently has no attractive applications. The concept of technology is open: in the future, stakeholders can replicate the concept with other raw materials and to produce other types of fuels. The torrefaction process technology was developed by the company
Torr-Coal, and the wood waste will be supplied by Renewi.

The Torero plant will convert wood waste into biocarbon suitable for the blast furnace process, which will reduce our $\mathrm{CO}_{2}$ emissions. It also offers a particularly difficult alternative to the current incineration of the wood waste stream. The initial idea is to convert 120 thousand tons of wood waste to about 50 thousand tons of biofuel each year in Toreros's plant, localized in Belgium (Torero, 2021).

Table 2 - Proximate and element analyses for biomasses in different conditions of torrefaction (Dong, 2015).

\begin{tabular}{|c|c|c|c|c|c|c|c|}
\hline Leucaena & Ash w/\% & Volatiles w/\% & Fixed C w/\% & $\mathrm{C} w / \%$ & H w/\% & $\mathrm{N} w / \%$ & O w/\% \\
\hline $25^{\circ} \mathrm{C}$ & 0.86 & 84.28 & 14.86 & 50.12 & 4.97 & 0.38 & 44.53 \\
\hline $182^{\circ} \mathrm{C}$ & 1.03 & 84.41 & 14.55 & 50.96 & 5.16 & 0.66 & 43.22 \\
\hline $206^{\circ} \mathrm{C}$ & 1.65 & 83.71 & 14.64 & 51.25 & 5.13 & 0.55 & 43.07 \\
\hline $220^{\circ} \mathrm{C}$ & 1.64 & 80.21 & 18.15 & 52.65 & 5.23 & 0.53 & 41.59 \\
\hline $248^{\circ} \mathrm{C}$ & 1.90 & 75.33 & 22.78 & 53.25 & 5.18 & 0.50 & 41.07 \\
\hline $273^{\circ} \mathrm{C}$ & 1.86 & 70.50 & 27.64 & 57.19 & 5.01 & 0.59 & 37.21 \\
\hline Eucalyptus & Ash w/\% & Volatiles w/\% & Fixed C w/\% & C w/\% & H w/\% & N w/\% & O w/\% \\
\hline $25^{\circ} \mathrm{C}$ & 0.74 & 87.40 & 11.86 & 48.83 & 4.94 & 0.20 & 46.03 \\
\hline $182^{\circ} \mathrm{C}$ & 0.57 & 87.48 & 11.94 & 50.28 & 4.84 & 0.22 & 44.66 \\
\hline $206^{\circ} \mathrm{C}$ & 0.65 & 87.79 & 11.57 & 50.71 & 5.04 & 0.28 & 43.97 \\
\hline $220^{\circ} \mathrm{C}$ & 0.54 & 86.70 & 12.75 & 50.84 & 4.84 & 0.25 & 44.07 \\
\hline $248^{\circ} \mathrm{C}$ & 0.65 & 81.63 & 17.72 & 52.65 & 4.98 & 0.24 & 42.12 \\
\hline $273^{\circ} \mathrm{C}$ & 0.70 & 75.26 & 24.05 & 55.81 & 4.87 & 0.18 & 39.14 \\
\hline Sugarcane Bagasse & Ash w/\% & Volatiles w/\% & Fixed C w/\% & C w/\% & $\mathrm{H}$ w/\% & $\mathrm{N} w / \%$ & O w/\% \\
\hline $25^{\circ} \mathrm{C}$ & 7.74 & 79.99 & 12.28 & 47.51 & 5.07 & 0.45 & 46.96 \\
\hline $182^{\circ} \mathrm{C}$ & 5.11 & 81.83 & 13.06 & 47.34 & 5.07 & 0.46 & 47.13 \\
\hline $206^{\circ} \mathrm{C}$ & 6.62 & 81.27 & 12.11 & 47.24 & 4.97 & 0.39 & 47.41 \\
\hline $220^{\circ} \mathrm{C}$ & 7.96 & 78.51 & 13.54 & 48.05 & 5.02 & 0.37 & 46.56 \\
\hline $248^{\circ} \mathrm{C}$ & 6.85 & 76.40 & 16.75 & 50.97 & 5.01 & 0.38 & 43.64 \\
\hline $273^{\circ} \mathrm{C}$ & 12.33 & 67.38 & 19.89 & 53.33 & 4.72 & 0.39 & 41.36 \\
\hline
\end{tabular}

\subsection{Biomass injection in blast furnace}

The most studied biomass for injection into the blast furnace is biochar, commonly charcoal. Different types of research have been conducted to evaluate the suitability of biomasses for the process. However, all of them agree that the important parameters for the process are reactivity, ignition, chemical composition and physical properties.

A very interesting test to evaluate conditions of injection is a physical simulation. Many tests were carried out, mainly with agribusiness residues, at the
Federal University of Ouro Preto, in a simulating injection laboratory, where it is possible to simulate some conditions of the blast furnace combustion zone. Figure 3 shows some results obtained in simulations carried out in the Federal University of Ouro Preto laboratory for some agribusiness waste.

In these tests, the combustion gas is collected and analyzed, and combustion efficiency is calculated. In Campos (2019), there are more details about the equipment and equations for combus- tion efficiency. It is possible to notice that some biomasses have a good combustion rate, better than coal, which can be an advantage for being injected.

Analogously, Silva (2008) performed a test in a simulator similar to the one used at the Federal University of Ouro Preto. This study compares three different types of coal (low, medium and highly volatile), as well as the mixture of coconut and soy husks. Figure 4 shows some results found by the author. 


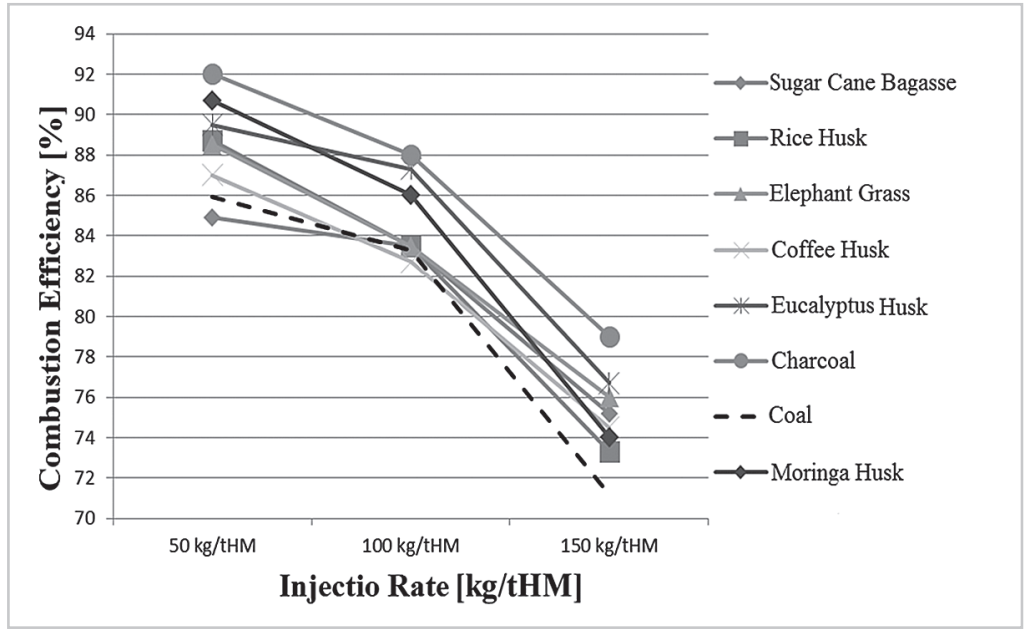

Figure 3 - Simulated results obtained in Federal University of Ouro Preto (Campos, 2018).

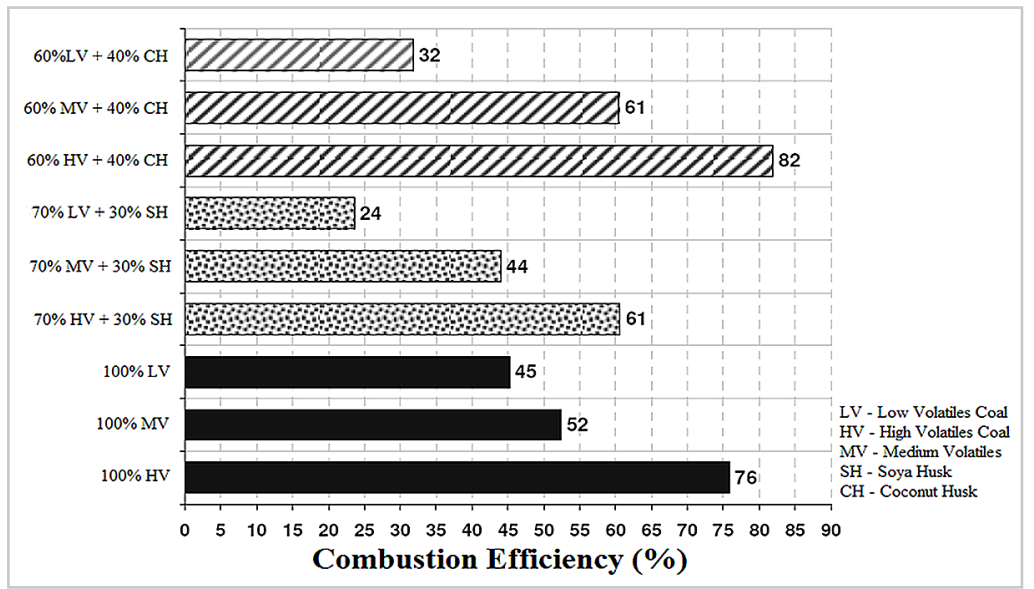

Figure 4 - Combustion Efficiency for some mixtures of biomasses and coals (Silva, 2008).

Another interesting research was performed by Pohlmann (2016). The combustibility of carbonized eucalyptus and injected coals having similar volatile matter contents (low, medium and highly volatile content) was compared. The author concludes that the burnout of biomass chars is higher compared to fossil coals with a similar volatile content. Another point is that the charcoal, or biomasses, has a porous structure. This can be interesting for the blast furnace process, since after the char leaves the raceway, it should react efficiently with $\mathrm{CO}_{2}$ to avoid soot formation.

There are some studies using computational simulation for analyzing the injection of biomass in blast furnace. Castro (2011) developed a six phase 3-D blast furnace model based on the multi-fluid theory to evaluate the injection of charcoal and pulverized coal. A blast furnace was simulated with stable operation and injecting $200 \mathrm{~kg} / \mathrm{t}$ of hot metal pul- verized coal and $50 \mathrm{~kg} / \mathrm{t}$ of hot metal pulverized charcoal. In addition, for the increase of biomass injection, high oxygen enrichment is needed to maintain the thermal conditions in the lower part of the furnace. In similar research of the same author, a high production and low coke rate was found when injection of $150 \mathrm{~kg} / \mathrm{t}$ of hot metal of coal and $100 \mathrm{~kg} / \mathrm{t}$ of hot metal of pulverized charcoal is performed (Castro, 2013).

Torrefied biomass is also being studied for injecting into the blast furnace. Du (2014) found that the burnout ratio decreases when the torrefaction temperature is increased. The burnout of fresh biomasses and torrefied biomasses are higher than low volatile coal, but ignition temperature is lower compared to the low volatile coal because volatile content is the main factor that influences the ignition temperature.

It is unanimous that torrefaction changes the chemical and physical properties of biomasses, which directly affects its combustion behavior in the raceway. Chen (2012) indicates that raw biomasses residence time in the raceway could be shortened, whereas biomasses torrefied at $300^{\circ} \mathrm{C}$ should have longer residence time in the raceway for efficient combustion. Figure 5 shows some results found by the author.

It is possible to note that burnout ratio versus fuel ratio can be associated with fixed carbon and volatile matter, it means, volatiles increase the burnout rate and decrease the fuel rate and fixed carbon do the opposite. Finally, the torrefied biomasses could replace high volatile coal in injection process, but not low volatile coal.

To increase the competitiveness of the steel industry, it is necessary to develop new technologies that must be sustainable in the long term. The use of biomass can attend this requirement economically and environmentally, since some infrastructure is provided. 


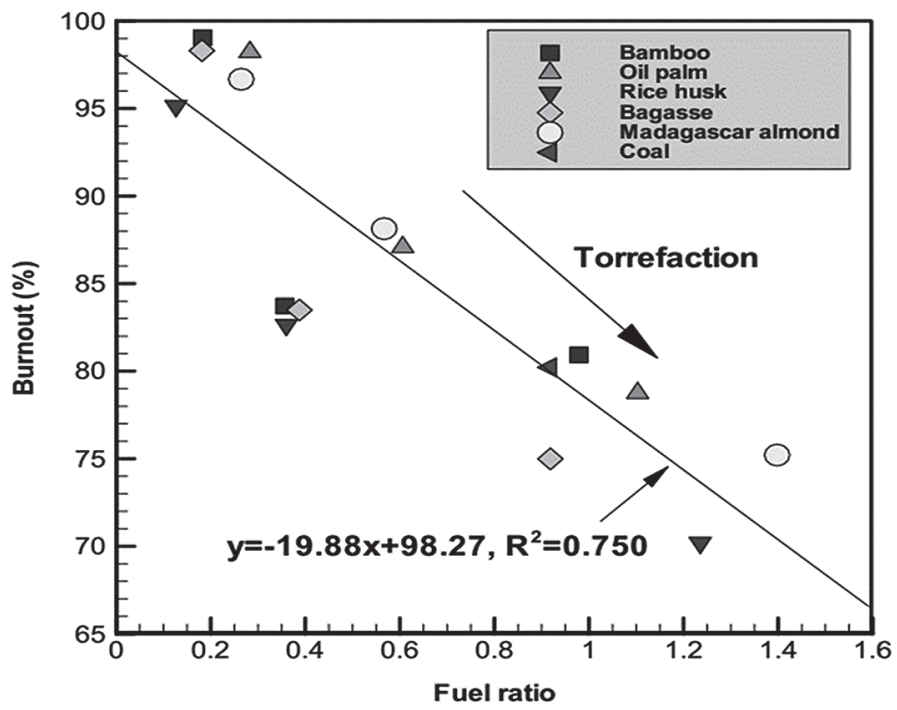

Figure 5 - Burnout versus fuel ratio of raw and torrefied biomasses as well as a coal (Chen, 2012).

\subsection{Environmental aspects}

Climate change has become one of the most important issues in global politics. The Kyoto Protocol, introduced in 1997, was the first international agreement to reduce greenhouse gases. The Paris agreement, signed in 2015 and valid since November 2016, determined the temperature increase of the planet in $2^{\circ} \mathrm{C}$ until 2100. This agreement was ratified by 179 countries that were in different stages of implementation and development of their environmental policies. Countries that have ratified the agreement recognize that the need to take action against climate change will imply accelerating policies and regulations that inevitably impacts the industrial competitiveness of all nations and their respective economies.

Greenhouse gas emissions are relevant in steel production. According to Holappa (2020), the steel industry is responsible for almost $10 \%$ of all $\mathrm{CO}_{2}$ emitted into atmosphere, one third of all the productive sector in the world. The main factor for these numbers is the large consumption of fossil fuels, coal and coke, which are essential in the blast furnace$\mathrm{BOF}$ route, which is the most productive route for steel production. In Figure 6, it is possible to see that the blast furnace is responsible for $69 \%$ of the $\mathrm{CO}_{2}$ emissions in the steelmaking processes, so this is where the efforts need to be concentrated.

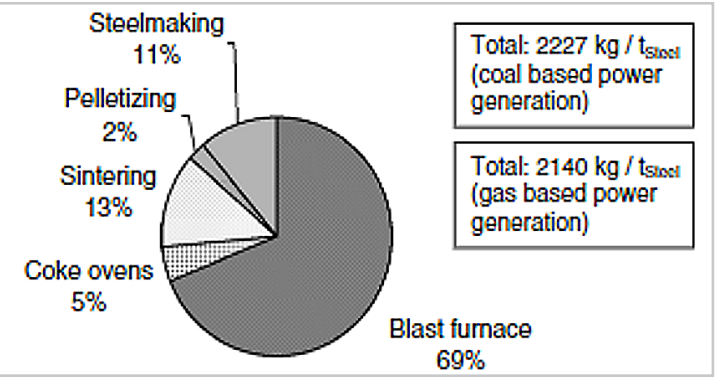

Figure $6-\mathrm{CO}_{2}$ emissions in steelmaking processes (Orth, 2007).

Considering the $\mathrm{BF}-\mathrm{BOF}$ coal route in which $2227 \mathrm{~kg}$ of $\mathrm{CO}_{2}$ is emitted for each ton of steel produced, taking only emissions from the blast furnace, this would be $1537 \mathrm{~kg}$ of $\mathrm{CO}_{2}$.

According to Sathler (2017), one
Brazilian steel company in 2016 had an average coke rate and injection rate of, respectively, $295 \mathrm{~kg} /$ ton of hot metal and $188 \mathrm{~kg} / \mathrm{t}$ of hot metal. For Silva, 2016 it is necessary 1.2 tons of coal to produce 1 ton of coke; so for the considered blast furnace, the consumption of coal to produce 1 ton of hot metal is $188 \mathrm{~kg}$ in PCI and $354 \mathrm{~kg}$ of coal in coke, each means $542 \mathrm{~kg}$ of coal.

Consider the Equation 1 presented by Carvalho (2003):

$$
1 \mathrm{C}+0.5 \mathrm{O}_{2}+1.88 \mathrm{~N}_{2}=0.9 \mathrm{CO}_{2}+0.1 \mathrm{CO}+1.88 \mathrm{~N}_{2}
$$

making a simple stoichiometric calculation, it is possible to say that burning 1 ton of carbon, 3.3 tons of $\mathrm{CO}_{2}$ (carbon molar mass is $12 \mathrm{~g}$ and $\mathrm{CO}_{2}$ is $44 \mathrm{~g}$ ) is produced. It is possible to find in literature concerning several coal characterizations, the average carbon content of them is around $85 \%$. With this, it is concluded that $542 \mathrm{~kg}$ of coal has $460 \mathrm{~kg}$ of carbon and its burning emits $1520 \mathrm{~kg}$ of $\mathrm{CO}_{2}$, which is a value very close to that presented by Orth (2007).

The main question is how many $\mathrm{CO}_{2}$ emissions can be avoided with the use of biomass in the blast furnace. For this calculation the following considerations were made:

- 1 ton of hot metal produce 1 ton of crude steel;

- Biomass burn is considered neutral in $\mathrm{CO}_{2}$ emissions, because of the photosynthesis;

- Emissions related to torrefaction, logistics and cultivation are not considered.

Studies by Assis (2014), Campos (2018), Suopajärvi (2017) and Wei (2017) 
on biomass injection into the blast furnace, point that is possible to inject around $40 \%$ of biomass in the mixture with coal without changing the operational conditions. Some studies use fresh biomass, not torrefied, so this amount could be increased. Taking these factors and all the calculations done before, it is possible to say that by replacing $50 \%$ of the injected coal by torrefied biomass, the amount of coal to produce 1 ton of hot metal becomes $448 \mathrm{~kg}$. Using the stoichiometric calculation, $448 \mathrm{~kg}$ of coal has $380 \mathrm{~kg}$ of carbon

\subsection{Economic aspects}

The steel industry is heavily dependent on the coal market. As it is one of the main inputs, and according to Silva (2016), and its burning emits $1256 \mathrm{~kg}$ of $\mathrm{CO}_{2}$, each means $264 \mathrm{~kg}$ less emissions per ton of hot metal.

This amount seems little, but when considering a world production, this value can be significant, According to the World Steel Association (2020), the production of hot metal in 2019 reached 1.2 billion tons, that is, if it were possible to apply the replacement of $50 \%$ of the PCI by injection of torrefied biomass, around 3.2 million ton of $\mathrm{CO}_{2}$ emissions would be avoided in a year.
Finally, considering that, according to Holappa (2020), in 2019 the $\mathrm{CO}_{2}$ emissions in the atmosphere reached $50 \mathrm{Gt}$ and that the steel industry was responsible for almost $10 \%$, with the replacement of $50 \%$ of the PCI coal by torrefied biomass, the steel industry would emit $7 \%$ less $\mathrm{CO}_{2}$. Obviously, this must be a common practise of steel producers and other measures can be taken, such as use biomass in other processes, but each effort counts for the sustainable development of the steel industry.

it is responsible for $40 \%$ of the steel production cost, any variation in the market, the price is affected and directly impacting the production cost. In Figure 7, it is possible to see the oscillation of PCI and coking coal prices along the years.

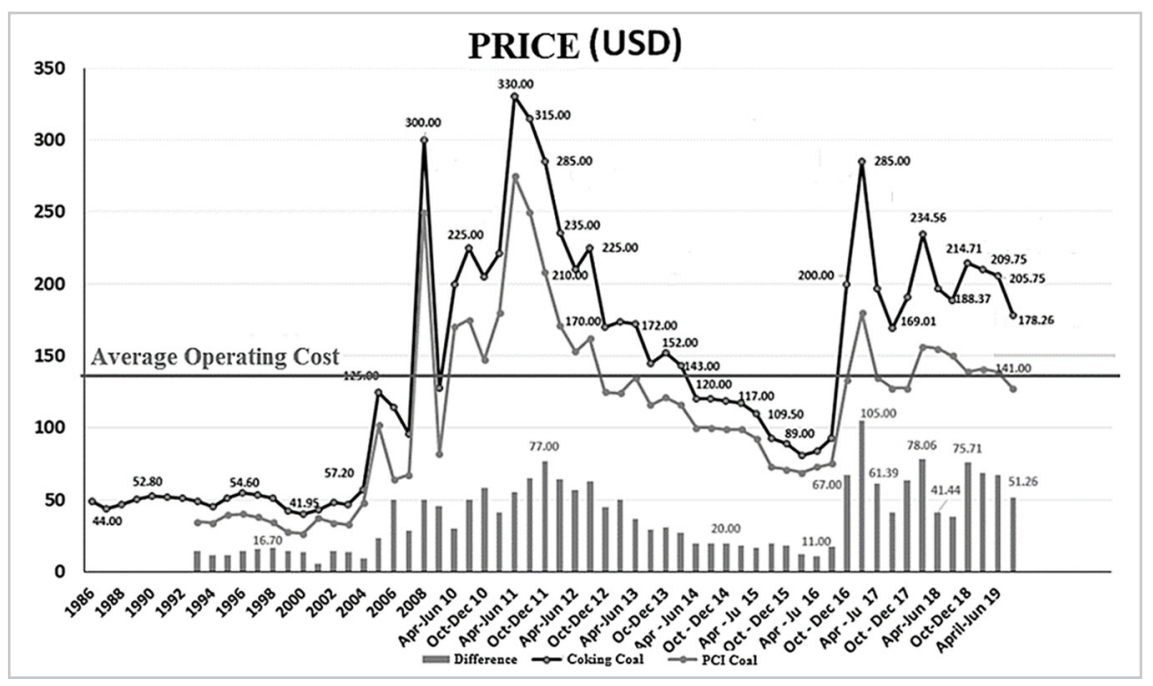

Figure 7 - Oscillation of PCl and coking coal process (Caldera, 2019).

It is possible to see that, for PCI coal, in 2019, the cost was in the range of 141 dollars, while coking coal was close to 180 dollars. This value for emerging countries is highly representa- tive because the American currency is overvalued, which makes this input expensive. Biomass is cheaper, especially if it is fresh or when it is a waste from agribusiness. In this case, costs can be attributed only to the transport and treatment of these biomasses.

Suopajärvi (2017) presented some biomasses prices as can be seen in the Table 3.

Table 3 - Biomasses prices (Suopajärvi, 2017).

\begin{tabular}{c|c|c|c|c}
\hline Feedstock & Technology & Location & Base Year & Cost $(€ / \mathbf{t})$ \\
\hline Chipped Wood & Torrefaction and pelletizing & Sweden & 2012 & 183 \\
\hline Sawdust and Shavings & Torrefaction and pelletizing & Canada & 2012 & 113 \\
\hline Logging Residue & Torrefaction & Finland & 2011 & 147 \\
\hline Small-diameter wood & Torrefaction & Finland & 2011 & 188 \\
\hline Debarked round wood & Torrefaction and pelletizing & USA & 2011 & 150 \\
\hline
\end{tabular}

For comparison we can use the cost of the biomass in American dollars, which in exchange rates of January 2021, 1 dollar is 0.83 euros. Therefore, the prices of a ton of chipped wood, sawdust and shavings, logging residue, small-diameter wood, and debarked round wood will be respectively $220,136,177,227,181$ dollars. Looking at these prices, the materials that would fit in the competition with the PCI coal are sawdust and shavings and logging residues. Remembering that these biomasses considered are already treated and, in the case of sawdust, it also consid- ers pelletizing in addition to torrefaction.

There is also the possibility for steel companies to invest in an industrial torrefaction plant. Erlach (2014) calculated that the cost of building a torrefaction plant with a capacity of 60000 tons per year would be around of 2 million euros 
or 2.4 million dollars. It is a considerable amount, but it can be viable in the long term. In addition, it must be considered that biomass will be the great opportunity for some hot metal producers since the global trend requires cleaner production.

Another interesting case is the use of agribusiness waste. Important crops for global supply such as corn, sugar cane, rice, coffee and others, produce a large amount of waste that can be used in the process. For these types of biomass, the costs and prices are still not very well established, most of them don't have a destination.

Ribeiro (2017) priced sugar cane bagasse based on the price of electricity. In this article, how much of electricity a ton of sugar cane bagasse generates and how much the concessionaires usually charge for the kilowatt were calculated. The estimated price for sugar cane bagasse was 200 Brazilian reais, considering the exchange of January 2021, 1 real is 0.19 dollars, so the price obtained for sugar cane bagasse was 38 dollars. These values do not consider the costs of treatment, only drying, and exclude transportation.
Similarly, this was done for sugarcane straw, which was priced at 183.42 reais or 34.85 dollars. It is important to consider that electricity in Brazil, where the study was made, is considered expensive, so it is possible to find fresh biomass at a better price.

Making some simple accounts, based on the previous examples and considering the price of PCI coal at 150 dollars, it can be said that the cost of this input for each ton of hot metal is 28.2 dollars (injection rate of $188 \mathrm{~kg} / \mathrm{t}$ of hot metal). When replacing $50 \%$ of this material by sugarcane bagasse $(94 \mathrm{~kg}$ of coal $+94 \mathrm{~kg}$ of biomass), for example, the cost would be 17.67 dollars per ton of hot metal (considering the price of the sugar cane bagasse shown previously). It seems like a very small amount, a savings of 10.53 dollars, but considering a steel company that produces 1 million tons of hot metal per year, that savings is around 10.5 million dollars.

This is not the only way to make money from the use of biomass in the steelmaking process. The commercialization of carbon credits can generate revenue for companies.

Based on the Kyoto protocol, market mechanisms were created, the main one being the Clean Development Mechanism. This allows projects in the energy, transport and forestry sectors to certify emission reductions and negotiate with countries that have signed targets within the protocol. The emission of one ton of $\mathrm{CO}_{2}$ now corresponds to 1 carbon credit. In addition, the reduction of emissions adds value to the company and attracts investment. Today there is a very high demand for sustainable investments such as BlackRock, which is the largest investment management company in the world, is making sustainability an integral part of the way it manages risks, builds portfolios, develops products and gets involved with companies (BlackRock, 2021).

Another important action to generate income is the ETS. The Emissions Trading System is a scheme for the trading of greenhouse gas emission allowances worldwide. The biggest and consolidated is the Europe Union ETS, with 30 countries. Figure 8 shows prices for carbon in some ETS.

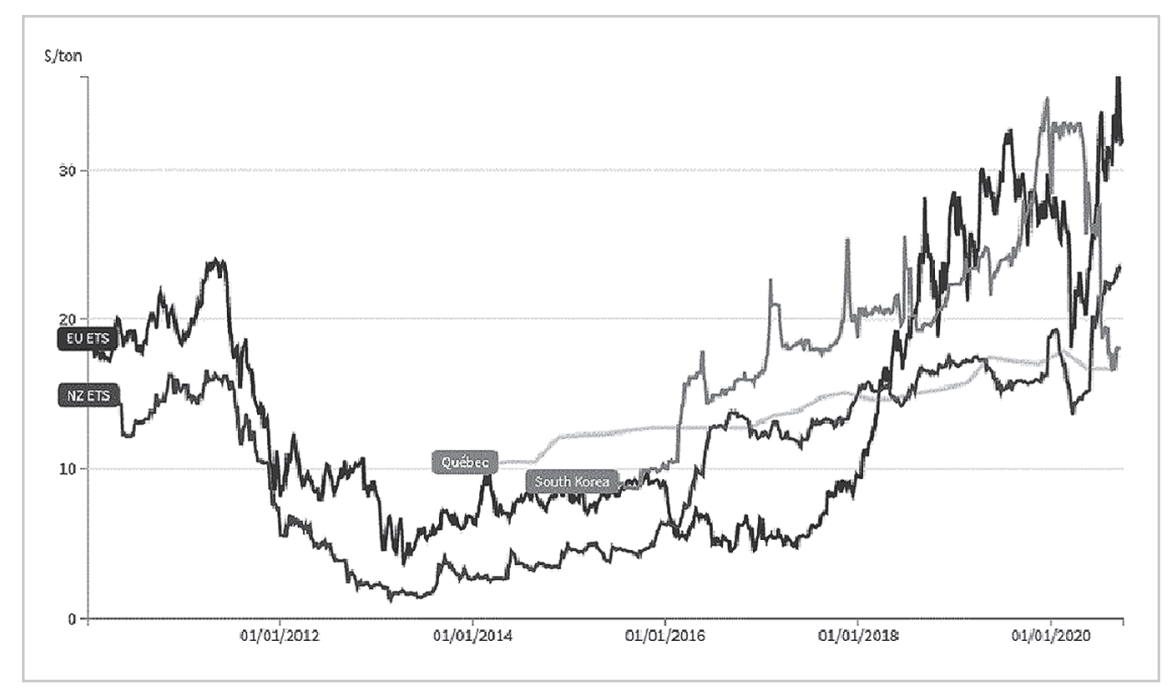

Figure 8 - Prices for 1 ton of carbon sin some ETS (ICAP, 2021).

The graph shows the price variation of 1 ton of carbon in the ETS of the European Union, New Zealand, South Korea and Quebec (which is a merger of the ETS of California, Ontario and Quebec). It is possible to see that after the Paris Agreement, the price of carbon increases rapidly reaching, in the end of 2020, US\$ 32 for European Union, US\$24 for New Zealand, US\$ 18 for South Korea and US\$ 17 for Quebec ETS.
To conclude, considering the value of carbon ton from European Union ETS, 32 Dollars, and calculated values of emissions when $50 \%$ of the coal is replaced by biomass in PCI. If a company produces 1 million tons of hot metal in one year, under the conditions mentioned, it avoids emitting 264 thousand tons in one year $(264 \mathrm{~kg}$ per ton of hot metal). Therefore, considering the European market, 8.4 million dollars would be generated in carbon credit, values that may be of interest to steel companies.

In many countries, the carbon market is still not well established, but this will be the future for everyone, sooner or later. They will have to regulate themselves and join this global movement. An important action for the sector is being prepared for this, with all the alternatives ready to be used and guarantee the survival of steel production via blast furnace. 


\section{Conclusions}

Due to the predominant model of steel production (BF-BOF), there is a strong dependence on fossil fuels, mainly coal. It is possible that the use of coal will not be totally extinguished from the steel industry because the blast furnace is a reactor that needs materials that supply not only thermal functions, but also physical and chemical ones. However, the partial replacement of this fuel can be highly viable and biomasses presents as a strong candidate to be used in blast furnace, mainly in PCI.

As it was seen, fresh biomass has some obstacles to be used directly as high humidity, high volatile content with low calorific value, low grindability and low energy density. It is interesting a pretreatment to prepare these biomasses for PCI. It has been shown that the torrefaction treatment increases fixed carbon of the biomass, eliminates the volatiles of low calorific value, increases the grindability, increases the energy density and produces a hydrophobic material.

The use of biomass in general can bring environmental and economic gains. For the use of torrefied biomass, it may be necessary to invest in a torrefaction plant, but it can be purchased already torrefied at a price slightly higher than the fresh one. Considering PCI coal and biomasses costs, found in the literature, it has been shown that it is possible to reduce costs of hot metal by 10 dollars per ton, a value that can be considerable for high production. Another economic advantage, with the use of biomass, is through carbon credits commercialization. Some countries already have a solid and active market, it has been shown that it is possible to generate 8 million carbon credits per year when $50 \%$ of
PCI coal is changed by biomass.

However, the great advantage is the environmental gain, reducing $\mathrm{CO}_{2}$ emissions in the process. The partial use of biomass in PCI decreases $264 \mathrm{~kg} /$ ton of hot metal in $\mathrm{CO}_{2}$ emission. Large companies that produce 1 million tons per year would no longer emit 264 thousand tons per year

Finally, it is important to say that the discussion of sustainable alternatives for steel industry is very important and should be encouraged for developing new alternatives for steel sector. Environmental restrictions are already being tightened and governments increase the pressure to control emissions. As a result, the steel sector must redouble its efforts to consolidate itself as a strong sector of the industry that cares about its impacts and always seeks to improve sustainable production.

\section{Acknowledgments}

The authors acknowledge CAPES, CNPq, REDEMAT, UFOP,
EcoEnviroX and all that contributed for this research.

\section{References}

ARCATE, J. New process for torrefied wood manufacturing. Bioenergy Update, v. 2, n.4, p. 1-4, 2000.

ASSIS, C.; TENÓRIO, J.; ASSIS, P.; NATH, N. Experimental simulation and analysis of agricultural waste injection as an alternative fuel for blast furnace. ACS Energy \& Fuels, v.28, p. 7268-7273, 2014.

ASSIS, C. F. C. Caracterização de carvão vegetal para a sua injeção em altos-fornos a carvão vegetal de pequeno porte. 2008. Dissertação (Mestrado em Engenharia de Materiais) - Escola de Minas, Universidade Federal de Ouro Preto, Ouro Preto, 2008.

ASSIS, P. S.; MARTINS, W.B.; VIEIRA, C.B. Avanços na injeção de carvões pulverizados para sua aplicação em altos-fornos. Rem: Revista Escola de Minas, Ouro Preto, v.56, n.4, p. 281-285, 2003.

BABICH, A.; SENK, D.; SOLAR, J.; MARCO, I. Efficiency of biomass use for blast furnace injection. ISIJ International, v. 59, n.12, p.2212-2219, 2019.

BLACKROCK. Sustentabilidade como novo padrão de investimento da BlackRock. [S. l.]: BlackRock. Available at: https://www.blackrock.com/br/blackrock-client-letter. Accessed: 15 Jan. 2021.

BROUWER, R. C.; SCHOONE, E. E.; TOXOPEUS, H. L. Coal injection driven to the limits. Iron and Steel Engineer, v. 69, n.1, p. 20-25, 1992.

BROUWER, R. C.; TOXOPEUS, H. L. Massive coal injection at Hoogovens IJmuiden BFs. Revue de Metallurgie. Cahiers d'Informations Techniques, v. 88, n. 4, 1991.

CALDERA, J. Mercado de carvões minerais: reflexões à luz do aumento mundial de demanda e seu impacto sobre as usinas brasileiras. In: ABM WEEK, 2019, São Paulo. Anais [...]. São Paulo: ABM, 2019.

CAMPOS, A. M. A.; NOVACK, K. M.; ASSIS, P. S. Avaliação técnica e ambiental da injeção da casca da moringa oleífera em altos-fornos a coque. Tecnologia em Metalurgia, Materiais e Mineração, v. 16, n. especial, 2019.

CAMPOS, A. M. A.; ASSIS, P. S.; NOVACK, K. M. Aspectos econômicos e ambientais do uso de biomassas na siderurgia. In: SEMINÁRIO DE REDUÇÃO DE MINÉRIOS E MATÉRIAS-PRIMAS, 48., 2018, São Paulo. Anais [...]. São Paulo: ABM Proceedings, 2018. p. 21-32.

CARVALHO JUNIOR, J. A.; LACAVA, P. T. Emissões em processos de combustão. São Paulo: Editora UNESP, 2003.

CASTRO, J. A.; ARAÚJO, G. M.; MOTA, I. D. O.; SASAKI, Y.; YAGI, J. I. Analysis of the combined injection of pulverized coal and charcoal into large blast furnaces. Journal of Materials Research and Technology, v. 2, n.4, p. 308-314, 2013.

CASTRO, J. A.; SILVA, A. J.; SASAKI, Y.; YAGI, J. I. A six-phases 3-D model to study simultaneous injection of high rates of pulverized coal and charcoal into the blast furnace with oxygen enrichment. ISIJ International, v. 51, n.5, p. 748-758, 2011. 
CHEN, W. H.; DU, S. W.; TSAI, C. H.; WANG, Z. Y. Torrefied biomasses in a drop tube furnace to evaluate their utility in blast furnaces. Bioresource Technology, v. 111, p. 433-438, 2018.

CORTEZ, L. A. B.; LORA, E. E. S.; GÓMEZ, E. O. (org.). Biomassa para energia. São Paulo: Editora da UNICAMP, 2008.

DONG, L. Impact of torrefaction on grindability, hydrophobicity and fuel characteristics of biomass relevant to Hawai'I. 2015. Thesis (Master of Science in Mechanical Engineering) - University of Hawai'I at Mānoa, Mānoa, 2015.

DU, S.; CHEN, W.; LUCAS, J. Pretreatment of biomass by torrefaction and carbonization for coal blend used in pulverized coal injection. Bioresource Technology, v. 161, p. 333-339, 2014.

ERLACH, B. Biomass upgrading technologies for carbon-neutral and carbon-negative electricity generation. 2014. Doctoral Thesis (Doktor der Ingenieurwissenschaften) - Institute for Energy Engineering, Teschnische Universität Berlin, Berlin, 2014.

FRAGOSO, H. A. P.; POHLMANN, J. G.; MACHADO, J. G. M. S.; VILELA, A. C. F.; OSÓRIO, E. Influência dos voláteis e do tamanho de partículas de carvões na combustão em Simulador de PCI. In: SEMINÁRIO DE REDUÇÃO DE MINÉRIOS E MATÉRIAS-PRIMAS, 48., 2018, São Paulo. Anais [...]. São Paulo: ABM Proceedings, 2018. p. 383-394.

HOLAPPA, L. A General vision for reduction of energy consumption and $\mathrm{CO} 2$ emissions from the steel industry. Metals, v. 10, n. 9, p. 1117-1138, 2020.

HUNTY, W. P.; PRICE, J. T.; GRANSDEN, J. F. Evolution of coals for blast furnace injection using a computer model. In: IRONMAKING CONFERENCE, 1990, Detroit. Proceedings [...]. Pittsburgh: AIST, 1990.

ICAP. Allowance price explorer. [S. l.]: ICAP, 2021. Available at: https://icapcarbonaction.com/en/ets-prices. Accessed: 15 Jan. 2021.

MOURÃO, M. Introdução a siderurgia. 2.ed. São Paulo: Associação Brasileira de Metalurgia Materiais e Mineração, 2011.

OLIVEIRA, G.; OLIVEIRA, V.; CÂNDIDO, L.; ASSIS, P. Estudo do fluxo de materiais pulverizados em simulador de injeção de ventaneiras de altos-fornos através de vídeo-fotografia. Tecnologia em Metalurgia e Materiais, v.3, n. 4, p.7-15, 2007.

ORTH, A.; ANASTASIJEVIC, N.; EICHBERGER, H. Low CO2 emission technologies for iron and steelmaking as well as titania slag production. Minerals Engineering, v. 20, n. 9, p. 854-861, 2007.

POHLMANN, J. G.; BORREGO, A. G.; OSÓRIO, E.; DIEZ, M. A.; VILELA, A. C. Combustion of eucalyptus charcoals and coals of similar volatile yields aiming at blast furnace injection in a $\mathrm{CO} 2$ mitigation environment. Journal of Cleaner Production, v. 129, p. 1-11, 2016.

RAMOS e PAULA, L. E. et al. Characterization of residues from plant biomass for use in energy generation. Cerne, Lavras, v. 17, n. 2, p. 237-246, abr./jun. 2011.

RIBEIRO, C. H.; SEABRA, J. E. A. Proposta de uma metodologia de precificação da cana levando em consideração a contribuição do bagaço e da palha na produção de eletricidade e de etanol de segunda geração. Revista Brasileira de Energia, v. 23, n. 2, p. 72-88, 2017.

SATHLER, F.; NASCIMENTO JUNIOR, R. C.; PERDIGÃO, L. P.; RIBEIRO, E. C.; WASEN, L.A. Projeto CR298: Altas taxas de injeção de carvão PCI com baixo Fuel Rate nos altos-fornos da ArcelorMittal Tubarão. In: SEMINÁRIO DE REDUÇÃO DE MINÉRIOS E MATÉRIAS-PRIMAS, 47., 2017, São Paulo. Anais [...]. São Paulo: ABM Proceedings, 2017. p. 159-169.

SILVA, G. L. R. Utilização de moinha de bioredutor e pneu inservível na produção de coque metalúrgico. 2016. Tese (Doutorado em Engenharia de Materiais) - REDEMAT, Universidade Federal de Ouro Preto, Ouro Preto, 2016.

SUOPAJÄRVI, H.; KEMPPAINEN, A.; HAAPAKANGAS, J.; FABRITIUS, T. Extensive review of the opportunities to use biomass-based fuels in iron and steelmaking processes. Journal of Cleaner Production, v.148, p.709-734, 2017.

SUOPAJÄRVI, H.; PONGRÁCZ, E.; FABRITIUS, T. The potential of using biomass-based reducing agents in blast furnace: a review of Thermochemical conversion Technologies and assessments related to sustainability. Renewable and Sustainable Energy Reviews, v.25, p. 511-528p, 2013.

TORERO. TORrefying wood with ethanol as a renewable output: large-scale demonstration. [S.l.]: Torero, 2020. Available at: http://www.torero.eu/. Accessed: 8 Apr. 2021.

WEI, R.; ZHANG, L.; CANG, D.; LI, J.; LI, X.; XU, C. Current status and potential of biomass utilization in ferrous metallurgical industry. Renewable and Sustainable Energy Reviews, v.68, p. 511-524, 2017.

WORLD STEEL ASSOCIATION. Steel statistical yearbook 2020: concise version. [S. l.]: World Steel Association, 2020. Available at: https://www.worldsteel.org/en/dam/jcr:5001dac8-0083-46f3-aadd-35aa357acbcc/ SSY\%25202020_concise\%2520version.pdf. Accessed: 15 Jan. 2021.

Received: 10 September 2020 - Accepted: 5 July 2021. 